\title{
Foreign Language Teacher Training in the Sudan: Past, Present and Strategies for Future Recruitment Policies
}

\author{
Dr. Ahmed Gumaa Siddiek \\ Dawadami Community College, P.O.Box 18 \\ Shaqra University, 11911, Saudi Arabia \\ E-mail: aahmedgumaa@yahoo.com
}

Received: May 14, 2011 Accepted: June 21, $2011 \quad$ doi:10.5539/ijel.v1n2p115

\begin{abstract}
The qualifying of teachers secures the attainment of the national educational objectives, but to achieve these goals, strict criteria about teacher quality must be utilized. However, it is quite clear that whatever measures are to be adopted to deal with these educational issues, it is always the teachers who will have to put these objectvies into reality. This paper is suggesting some ideas to improve the teaching profession. The recent recruitment policy of teachers in the country attracts only the poor achievers, who are unwilling to teach but they aspire to just get a degree. This paper suggests abolishing all colleges of education and encouraging the future teacher to join a one-year training course after $\mathrm{s} /$ he has got his/her BA or B.Sc. This policy will attract the willing persons who are serious to take teaching as their profession. Then the candidates can spend this one academic year to be equipped with necessary pedagogical knowledge to qualify to manage his/her classroom efficiently and carry out effective classroom presentation. By this recruitment policy, we can guarantee the sustainability of the process, and that only the willing persons will come to take teaching as their future career.
\end{abstract}

Keywords: Foreign language education, Teacher training, Imparting knowledge, Criteria recruitment

\section{Introduction}

Education is a headache issue for educators and decision makers in this modern times, as highly competitive and qualified workforce is drastically needed to keep sustainable growth and steady socioeconomic development in every country. Education is a thorny issue for all governments, as it a factor of stability to the political ruling group if the educational programs satisfy the needs of the individual person and serve the practical needs of the community. On the other hand, education can be an element of social turmoil in the country, when it fails to secure the personal and communal needs of the society. This happens when the educational objectives mismatch the political orientation and direction of the ruling factions.

Language education is an important part of education. It is a personal and communal need in this modern time. It demands serious efforts from educators and decision markers to make it yield positive results. Languages are vehicles of thought, feelings and means with which we are able to exchange benefits, one person with another or one community with the other. But, language teacher education as Freeman:(1989), sees it has become increasingly fragmented and unfocused. Based on a kaleidoscope of elements from many disciplines, efforts to educate individuals as language teachers often lack a coherent, commonly accepted foundation. In its place, teacher educators and teacher education programs substitute their own individual rationales, based on pedagogical assumptions or research, or function in a vacuum, assuming-yet never articulating-the bases from which they work. What is needed, then, Freeman: (1989), thinks, 'is an understanding on two levels: a view of what language teaching is and a view of how to educate individuals in such teaching. We need to define the content of language teacher education.' Then language education will be a real concern of the educationists, the economists and the politicians, because this kind of education is directly or indirectly a source of power and wealth.

Politically, foreign languages education is a powerful tool, in the hands of powerful nations, through which they can impose economic and cultural control upon the weak and undefended minorities. And as it is often cited that language travels with the flag, therefore the English language spread where the British army had set their camps, and so did the French and Spanish. Then, those who can afford exporting their languages could afford marketing their cultural and economic products outside their native lands, simultaneously. These products would later be tools of exerting political and economic power as well as cultural supremacy. Languages education can be seen from an economic angle, as language and trade are twins. People often, willingly or unwillingly, inherit the cultural habits of their old colonizers. A Francophone elite from Africa or Asia would prefer to drive a Peugeot 
made in France, whereas an Anglophone elite would prefer to smoke British cigarettes. So there are always inextricable and strong ties between language, trade and culture. The culture of the language always engineers the entire behavior of the consumer to make him positive and enthusiastic toward those cultural products of old masters. The writer himself is an example, as he likes to carry out his research in English and he is keen to follow the British style of spelling. In addition to that, language education is a considerable source of income that feeds some national budgets with millions of dollars, pounds, francs and pesos, as it's the case in America and Britain with the English language and the French and Spanish in Spain and France.

At the local level we need to care for the language education as language is our way out for importing knowledge and know-how to our people in their native places. The modern technology and sciences are precious products, but since we are not producing our sufficient needs, we have to import them from outside. The Internet is a reliable source of data and English in particular, is needed to enable us browse and download our needs from these very informative and educative machines.

Sudan is a part of all of this. It affects, but mostly affected by the events that are running so fast in the political, economic and social arena. Education - among other things -is a tool if used properly it would yield positive results and prosperity to the people. Language education is one active way to interact with the international community. This paper is addressing the issue of English teachers training programmes in the Sudan, as these teachers are the ones who are meant to impart knowledge to our community through language education to make considerable social, economic and cultural change in our society.

\section{Teachers' Training, Education and Development}

These three terms are keywords in the literature of teacher education. Therefore, we need to technically examine them to see what they mean.

\subsection{Training and Education}

According to Widdowson, (1983:24) to train is to instill habits or skills, and the word collocates just as happily with dogs and seals as with teachers. To educate, on the other hand, is to guide towards moral and intellectual excellence. Widdowson believes that the difference between training and education (at least as far as language teaching is concerned), that training seeks to impose conformity to certain established patterns of knowledge and behaviour usually in order to carry out a set of clearly defined tasks. Education, however, seeks to provide for creativity whereby what is learned is a set of schemata and procedures for adapting them to cope with problems which do not have a ready-made, formulaic solution.' Widdowson (1983:24) goes on to express a widely held view when he says that "we think it is more important, in training teachers, to produce well-educated people than to produce technically competent practitioners."

\subsection{Teacher Development}

Training and education, competence and capacity are themes strongly interwoven but they suggest that everyone has the potential to be the best teacher that one can be, but this criteria is based on personal qualities. What a teacher needs to develop is a sense of strengths and self realization which can help in developing self-awareness, and realization of the importance of the teaching profession as a helping profession that develop peoples' mental, psychical, psychological and spiritual growth. This perspective on teacher; development as Barduhn:(1989:2-3) believes, draws in other aspects of the life of the teacher. For example, teaching can be a highly stressful occupation. [And] the only way to escape this type of stress is through the development of a sense of inner security which allows for the development of secure personal relationships with colleagues and learners. Teacher training is about competence in the implementation of teaching techniques, and teacher education is about the capacity to choose among various techniques and improvise new ones, teacher development. According to Stones:(1984:180), Handal \& Lauvas:(1987:65) teacher development characteristics have two definitions: First, it concerns itself with the development of the socially aware individual as a whole-person-who-teaches, as opposed to the acquisition of professional competence and capacity by a teacher, separate from the rest of that person's life. Second: The emphasis here is on the personal motivation of the individual to take responsibility for his or her own self-development. Training and education are what other people can give you; development is what the teacher does about himself/herself. The influence of such ideas as these has been seen in the teacher education courses for some time, perhaps most clearly in what is often called a counseling approach to observation and feedback.

\subsection{English Language Teacher Training}

Due to the international nature of the English language, English language teacher (ELT) training programs are being implemented all over the world. Considerable attention has been given to the process of training English-as-a-foreign-language (EFL) teachers. Topics such as the nature of teacher-training courses, different approaches to language teacher training and several paradigms of teacher-training methodology have been discussed at conferences throughout the world. 


\subsubsection{Teacher training programme Diversity}

Williams (1949), mentions the diversity of these teacher-training programs (which vary considerably in terms of length and qualifications) and discusses the nature of the ELT-training discipline in terms of its uniqueness. Further, he discusses factors that should be accounted for in a teacher training model, e.g., cultural appropriateness, political influences, teacher background and competence, expectations from students, cost, and accountability. In addition, much concern has been expressed in the literature regarding the content of teacher training and the processes and methodologies of training programs.

\subsubsection{Communication vs. Knowledge}

Although in most parts of the world the main emphasis in ELT is on methodology, there have been situations in which emphasis was placed on raising the language level of the future teacher. In such a case, attention is given to linguistic knowledge of the language rather than the ability to use the language for real communication. Cullen: (1994:163-171) states that only a few teacher training courses are able to achieve the objective of improving the communicative command of the language rather than knowledge of it. Cullen, however, recognizes that in most regions of the world, especially where English is not a medium of instruction, the main interest of English teachers is the need to improve their own command of the language so that they can use it more fluently, and above all, more confidently, in the classroom. Language proficiency has indeed constituted the bedrock of the professional confidence of non-native English teachers. Language competence has been rated as the most essential characteristic of a good teacher. Lange: (1990:50).

\subsubsection{The Components of training programmes}

Berry: (1990:97-105) conducted a study of two groups of English teachers teaching at the secondary level in Poland. They wished to discern which of three components (methodology, theory of language teaching, or language improvement) they needed most. Language improvement was ranked as the most important for both groups, and methodology was second, while the two groups ranked theory a poor third. This is the case not only in Poland but in many other countries with similar conditions. For instance, contact with native speakers of English was seen as one of the most pressing needs among 53 teachers of EFL in Russia and the Ukraine in a survey by Schotta:(1973:502) of their perceived needs and concerns. The EFL teachers also indicated a desire to improve their teaching methodology and to increase contact with colleagues both locally and nationally. Fahmy and Bilton:(1992) examined the undergraduate, teaching- English-as-a-foreign-language (TEFL) education program at Sultan Qaboos University in Oman. Students were found there to be aware of their need to improve their English language skills, and they recommended language support in the program for as long as needed. Berry: (1990: 97-105) sees that the first function is obvious, i.e., raising the teacher's level of proficiency. The second function is very subtle and consists of providing effective teaching models when changes are desired in teaching practices. Murdoch (1994: 253-259), suggested that teacher-training programs should think more in terms of activities that will help develop both the pedagogical skills of the trainee and his or her language competencies.

\subsubsection{Professionalism \& Self esteem}

According to Doff (1987: 67-71), a teacher's confidence in the classroom is undermined by a poor command of the English language. Poor command of the language through lack of use can affect the self esteem and professional status of the teacher and interfere with simple teacher procedures. Furthermore, it can keep the teacher from fulfilling the pedagogical requirements of a more communicative approach to language teaching. So knowledge as Buchmann:(1984), claims gives the teacher both social and epistemic control of the classroom environment and helps facilitate control of management problems. A foreign language teacher's lack of proficiency leads students to believe that learning a foreign language consists of the completion of textbook activities rather than learning the language for the purpose of communication. Teacher-preparation programs according to Schrier (1989:59-74) must be in three ways: general, specialist, and professional education. Foreign language departments have the most influence in the area of specialist education because of the content knowledge preparation or simply the knowledge base. Knowledge base is described by Valli and Tom (1988:5 -12) as the "entire repertoire of skills, information, attitudes, etc., those teachers need to carry out their classroom responsibility". Knowledge base can be conceptualized in many ways, depending on the approach.

\subsubsection{What knowledge do teacher trainees need?}

Investigations have been made in attempts to specify clearly the knowledge that teachers should have. Several categories have been generated, ranging from knowledge of educational contexts, content, curriculum, and educational goals and values, to familiarity with new technology, knowledge of statistics, research methods, and insights into cultural influences on learning. Shulman:(1992:250-262). Several other variables must also be taken into account in order to change, and thus improve, the education process. Such variables, according to Reilly:(1973: 9-13) would include "the mission of schools, the organization of schools, the programs offered by 
schools, the means by which content is taught to students, and required changes in teacher education curricula". Shulman (1992: 257) states that "a knowledge base for teaching is not fixed and final. . . . It will, however, become abundantly clear that much, if not most, of the proposed knowledge base remains to be discovered, invented, and redefined".

Morain:(1990:20-24) however, points out that educating the foreign language teacher is not the responsibility of a single segment of academe, (language proficiency for example) but rather the combination of four components, which are (1) required language courses, (2) courses in the content area, (3) courses in pedagogy, and (4) in-school experience. Schrier:(1989) on the other hand, outlines four characteristics desirable in future foreign-language teachers. Schrier:(1989) emphasizes the role of community as he sees "the role that the foreign language community plays in this process goes beyond providing content knowledge. It is the way professors organize and deliver this knowledge that provides future teachers with the scripts for understanding the structure and process of learning a language". But what is the best component of teacher training module? Gradman:(1971) proposed the following as ideal components of teacher preparation programs: knowledge of language, language acquisition, and historical and current methods of language teaching, materials and error analyses, measurement and testing, and the prerequisite of competence in English for ESL teachers who are non-native speakers of the language. In addition, he suggests including culture, as well as literature and research techniques.

\subsubsection{Literature \& more Literature?}

As you will see later, literature takes a considerable time in the Sudanese curriculum in the colleges of education. How much literature do you think we will need? Brickel and Paul:(1981) conducted a survey of secondary schools. He found that teachers at the secondary schools reported that during their FLT preparation they spent more than $50 \%$ of their time studying literature. A similar study of FLT preparation programs was conducted by Schrier:(1989) in four-year colleges and universities. The study revealed that $56 \%$ of the 500 institutions surveyed still place great emphasis on the study of literature. Morain:(1990), reports that, at the University of Georgia, three out of six courses in education are devoted to the teaching of foreign language and culture, while thirteen courses are in language specialization. The problem, however, is that "the number of courses taken has no predictable correlation to the linguistic and cultural proficiency attained by the takers. Morain:(1990) suggests courses designed to increase oral fluency, such as the art of storytelling, or a course in role playing and dramatics. The teaching of discussion and persuasion are other techniques that could benefit students.

\section{History of the English Language in the Sudan}

The history of English in Sudan began with the advent of the first colonizers to the Sudan in 1889. The Agreement of the Anglo-Egyptian condominium, by which the Sudan was governed, was the beginning of the British rule under the auspice of Lord Cromer who wrote advising Lord Kitchener, the conqueror of the Sudan and Sir James Currie, the first director of Education that,
"I wish, however, to explain what I mean by educated class. I do not refer to high education. What is now mainly required is to impart such a knowledge of reading, writing and arithmetic to a certain number of young men as will enable them to occupy with advantage the subordinate places in the administration of the country. The need for such a class is severely felt." Eltigani:(1966:7)

This education was given in the Gordon Memorial College started in 1902- as a primary school and later developed into secondary school with vocational bias in the senior forms. It was decided to follow a three- stage pattern from the beginning - elementary, intermediate and secondary. So by this policy, it had been decided that English should be the language of official correspondence. It was decided that the English language should be taught in intermediate and secondary stages. Then it was taught in the intermediate stage as school subject and used as a medium of instruction at the secondary level. Moreover, it was decided that a pass in the E.C.E Part One (for the intermediate stage and in the E.C.E Part Two) was the main requirements for admission to government jobs, or even to jobs in private business, Eltigani:(1966:7-8). So by imposing this strategy, English became a passport for gaining official post in the government office. Mastering the language was a good means for financial security and social prestige. The teachers who did the job were almost British, with some Syrian and Egyptian who taught other academic subjects in English.

\subsection{English Language Teacher Training in the Sudan}

The expansion of the government business led to the thinking of training teachers in Sudan, as early as the beginning of the last century during the condominium rule. In 1900 an intermediate school was opened with a training college attached to it, which became a part of Gordon Memorial College in 1903. In 1906 a section for training intermediate school teachers was opened with a period of four years. The training period was divided 
into two sections: the first two years were for the study of languages and general subjects, and the other two were for the study of methods of teaching English Language, Arabic Language, mathematics, history and geography, both theoretically and practically. Bashir:(1970). The year 1934 witnessed a great development in the training of teachers, as the training system of teachers became prominent by the establishment of Bakht er-Ruda Training Institute. For the institute to play its role effectively in preparing competent teachers -who can work with high efficiency in rural areas-the site of the institute, was deliberately chosen to be about a mile north of El Dueim in the White Nile State of central region. This rural environment was suitable for training teachers to endure the hardships which they would except to face when they have left to schools in the different regions of the country. Students were trained to live the simple life of the rural people. They were to get water from well by themselves. They used their simple kerosene lamps for reading and revising lessons. This was typical to the life which they would lead when they have left the institute. At the beginning the training system was thought to be in-service then later changed to be pre-service. Up to 1939 the span of the study was four years after finishing the primary school, but in 1941, the first group of five-years of study was graduated. Then the system was changed to six years after finishing primary school, where the first group was graduated in 1945.

\subsection{ISETI Experience in teacher training in the Sudan}

Bakht er-Ruda and similar institutions continued to play their role in primary and intermediate teachers' training till the application of the new educational ladder in 1971. This change was due to the need for the recruitment of a huge number of teachers to fill the shortage in the primary schools. The increase in numbers of years from four to six at the primary level, led to the thinking of new institution to train that huge numbers without leaving vacuum in schools. So the In-service Educational Training Institute (ISETI)) was established in 1972 after the change of the educational ladder from 4:4:4 to 6:3:3 which led to recruiting more teachers, who had only finished their secondary school and did not receive any kind of teaching training. The training centers were chosen to be near the trainees' schools. (Rajaa: 2004). ISETI followed the Integrated Multimedia Approach which was based on part-time work instead of the full-time study that was used to be followed by Bakht er-Ruda and similar institutions.

According to Rajaa:(2004) the approaches which used were: First: Indirect components modules: for self study by the student-teachers specially prepared for such kind of study to increase interaction between the student-teacher and the writer of the module. These modules contained subject matters, educational psychology, methodology components with many activities to be done by student teachers on their own. Second: Direct components: There were Weekly seminars where the student-teachers met with their field tutors to discuss the activities in the modules. The school visits were done by tutors to follow up the implementation of the ideas and techniques discussed during the weekly seminar. ISETI expanded its role to train intermediate school teachers up to 1976 to help in training of the increasing number of untrained teachers at the intermediate level. The modules were prepared in a self study format and were distributed for the participants before the seminars twice a weekl.

\section{Modern Changes}

According to Yeddi:(2003:45), an effective and realistic teaching was needed to counteract the condition created by the Arabicization of secondary schools. A new Educational Ladder was established in 1972 and new syllabus of English for the Sudan was adopted to meet the situation emerged as a result of the change of the educational ladder from $4+4+4$ to $6+3+3$ to tackle the steady decline in standard of English language. But due to decrease in the number of years of teachings English which was changed from $4+4$ to 3+3, the mastery of English became worse so it was suggested at the end of 1982 to make some change, so Julian Corbluth was assigned the task of producing new integrated course for both basic and secondary levels. Sandell:(1982:22). The six books known as (Nile Course) were integrated, one book led smoothly to the next and there was no gap between general and the higher secondary school materials. The vocabulary and grammar of the whole course were worked out before the writing of course. The Nile course series were integrated with a few exceptions. An active approach had been adopted by stressing the use of English in communicative situations in actual real life situation.

\subsection{The Higher Teacher Training Institute in Omdurman}

This institute was established in 1961 as a joint project between the UNESCO and the government of the Sudan. The institute was meant to provide training for teachers to cover the needs of the Sudan at the secondary school level in the main subjects of sciences and arts. It was also expected to provide training to some African candidates, but it seems that the Sudan had the lion share as there was very poor enrollment of foreign students in the institute. It was a four year course after which the student-teachers were to be given higher diploma as licensed teachers who can carry the job professionally at secondary schools after they have finished the theoretical and practical requirements of that diploma. As the stipend was so attractive students preferred HTTI to even college of medicine, pharmacy and engineering. The influence of this attractive educational recruitment policy yielded very positive results, as those teachers were very good at their school subjects and professionally expert in the field of education. 
Due to high professionalism, the Sudanese teacher was highly demanded in the Arab and African neighbouring countries. The (HTTI) was lately affiliated to the University of Khartoum in 1974 and students were awarded BA \& B.Sc degrees in education but there was no longer a stipend paid to attract the brighter students to the college. The admission was decided by the admission office depending on the general competition of university entrances requirements in the Sudan. This new policy was no longer attractive as the low achievers in the Sudan School Certificate Examinations were the ones, who were admitted to the collages of education all over the country but unwillingly. Colleges of medicine and engineering in particular and colleges of applied sciences in general were more attractive to students rather than colleges of education. In 1994 the system of recruiting teachers and training them in intermediate institutes was abolished. Then students were to follow their education in the colleges of education affiliated to universities all over the country. A college of education was directly adjoined to almost all universities, with two departments: science and arts. These colleges gave B.A, B.Ed or B.Sc in a major field of academic disciplines and a minor.

\subsection{Deterioration of English in Sudan}

By applying such kind of training education was expected to witness development, but continuous deterioration was observed. Researchers and educators quoted many reasons behind the deterioration of language education and language performance-English in particular -in the country. Here we may mention some of these causes.

\subsubsection{Arabization}

The Sudanese can be classified as African people dominated by Arabic and Islamic culture. This situation is similar to many African countries that adopt either Anglophone or the Francophone languages and cultures, but they still remain African in their moods and in their beliefs in their belonging to their African continent. But the situation is different in Sudan where the Arabic-Islamic culture is dominant and it was one of the reasons behind the ethnic clashes between the Sudanese in the civil war that lasted more than half a century. This claim of belonging to Arab ethnicity (blue blood) led to the adoption of Arabization in the country culminated after the coupé d'état of Basheer Islamist Regime, which took government in 1989 and issued Islamic rules and called for the Arabization of government and Education. This philosophy immediately led to decrease of English language as the number of years in the primary education stage was decreased from 12 years to 11 and the number of English language periods were decreased from 8 periods per week to only 4 .

\subsubsection{Teachers' Qualification}

The second obvious reason behind the deterioration of language education was due to untrained teaching forces that were directly recruited from secondary after 11 years of education; and who were allowed to teach at the primary school age (6-11). The other group came directly from university with general BA or B.Sc degree in any academic discipline from geography to chemistry. They immediately got into classroom with no teaching background in the profession.

\subsubsection{Economic and Sociopolitical factors and Teacher migration}

The Sudanese teacher had developed long history of good teaching practice, a thing that was reflected in being demanded in the petro-dollar Arab states where the best teaching personnel were recruited as contactors with good pay compared to their status in the country. This foreign recruitment of our best teaching force caused great harm to economic, social and cultural domains in the country. Many qualified language teachers deserted the country due to economic, social and political factors which were/ are behind this severe brain drain. Some even have left the country for good.

\subsubsection{Language Syllabus}

The syllabus itself witnessed much development from the Readers of Michael West to Culbrith's (Nile Course), up to Spine Series in 1982. But most of the research carried out in the securitization of this syllabus showed great disinterest in the attitudes of language teachers towards these textbooks. They were simply criticized as irrelevant to the Sudanese student's needs and wants. The syllabus practically did not take into account the recent developments in the field of language pedagogy where language courses should be of practical use to the learner and secure his/her daily practical needs in lively access and positive communication with people. There was very little use of knowledge gained from those textbooks. Students felt that those books did not solve or help to solve their live problems, in direct contact with people or in helping them gain knowledge from free reading recourses. As a language teacher in secondary school and then university lecturer I was in a good position to see the pitfall of the courses. In a research carried out by me in 2004, I came with the truth that through the analysis of the examinations of the General Secondary School Certificate Examinations; those examinations:

- lacked content validly

- were incomprehensive

- were proficiency test rather than achievement tests. 
- were unreliable

- were invalid

- were impractical in formatting and marking.

- had very little washback or none at all. See (Siddiek:2004)

4.2.5 Poor School Environment

The poor qualification of school was a highly discouraging factor that did not encourage willing future teachers to join the teaching profession as new members. Schools lacked the basic infra-structure from the teaching aids to sanitary needs. Huge numbers of students were stuffed in small unconditioned classroom. Shortage of textbooks and educational aids made the teacher's job an impossible mission.

\subsection{Syllabuses at Tertiary level}

One quick look at the syllabus taught at these colleges could give us a good clue especially with language teaching. Let's for example take the syllabus of the College of Education in my own university, where I had been teaching in the Sudan the college offers a programme of 154 credit hours. Theoretically, this is very much looked like international standard. So, where does the problem come from? The problem is within the syllabus which is taught to these young teachers of English. Most of the courses deal with literature from Homer and Chaucer to Virginia Wolf and Wall Soyinka. There is too much focusing on literature from the old ages to the mediaeval to the $20^{\text {th }}$ century writings. There is always literature and more literature. Out of the total credit hours 30 hours are university requirements. They are not directly associated with teaching or education. Another 30 credit hours are elective courses for the college requirements as additional activities such as music, sports or theatre and the remaining credit hours are allotted to English. Generally, about only $50 \%$ of the total credit hours remains for teaching. But literature is dominant as it takes more than $50 \%$ of the course capacity. There is very little room for teaching methods, educational sciences such as developmental psychology, educational psychology, philosophy and history of education, language assessment, school and classroom management, special teaching methods of English etc. So stuffing of trainees would not allow time for them to qualify in education knowledge and teaching practice.

\subsection{Future Perspectives}

We need to think in qualifying and improving the school environment in general and the language teacher in particular. Teaching as we know is the profession that teaches all professions. So bright teachers will definitely help us to secure our national, local and personal educational objectives. I do believe that behind any failure student there was always a failure teacher or instructor. The same formula is applicable to societies as well. So we can easily infer from that behind any failure society there were/are failure teachers. The opposite is absolutely true and the whole truth. Teachers are responsible for the development of the total intelligence of their nations. They are responsible for the mental as well as psychological and spiritual growth of the young generation. This great task should be assigned to qualified teaching force. Consequently, an unwilling teacher will do great harm to society as $\mathrm{s} / \mathrm{he}$ will spoil the whole educational process.

Education is no longer the concern of governments alone. It has become the concern of every individual in the society. The internationally arena witnesses very big change in the orientation towards investment in the human capital. There are small nations in size of population and limitation of land space, but they have invested heavily in the human resources. The USA in 'NO Child Left Behind' and the European states always take the lead. There are also some highly successful attempts in Asia in India, China, Korea, Singapore and many other Asian countries. The educational experiences of these people need to be scrutinized and implemented in our developing counties.

Language education is one of the concerns of international organization such as the Unseco, regional and local organizations all over the world. Individual states cater for language education by encouraging its people to learn and communicate effectively in foreign languages. It is even the concern of leading figures such as USA president. On his campaign trail, then-candidate Barack Obama stressed that foreign language instruction should be expanded in American schools. "I don't speak a foreign language. It's embarrassing," he said. "It's embarrassing when Europeans come over here, they all speak English, they speak French, and they speak German. And then we go over to Europe and all we can say is merci beaucoup, right?" (examiner.com)

\subsection{Relevant Literature}

Mohammed:(2009): (Evaluation of Sudanese experience in teacher training. In this study, the researcher covered the historical development of Sudanese teacher training which began by opening Bakht-Errudha Institute for training primary school teachers in 1934. Then it was followed by opening a college for junior secondary school teacher training in 1949, and in 196, the ministry of education and the UNSECO signed an agreement to establish a higher institute for training secondary school teachers. This HTTI was affiliated to Khartoum University as College of Education in 1974 to give graduates B.Ed in Arts and Sciences. Since 1994 the colleges of education became responsible for the training of the elementary school teachers. 
In his study, Mohammed:(2009), found that most colleges of education did not have specific mission or vision. They had very ambitious unfulfilled goals. These colleges lacked complete effective administrative system in addition, most of the staff remembers lacked the suitable qualifications and experience to help qualify teachers. Mohammed was not happy with the criteria for the selection of trainees. He found that most of trainees were low achievers. He talked about the syllabus in these colleges where he found that most colleges tended to theoretical teaching rather than practice in teacher training. He also found that the infrastructure was poor and the educational aids were totally lacking. There were poor library recourses. He found that the research work was weak and most of the researches were carried out as part of graduate requirements. He also found that there was poor relationship between those colleges and community factions. It might be due to lack of clear policy or lack of financial resources. He found that most of the candidates were low achievers. They were unwilling to take teaching as a profession. He found in a survey in some Arab countries that from (8334) candidates (70\%) were unwilling to be teachers. Mohammed recommended the following:

- The college of education should have sound criteria for the selection of future teachers as to attract bright students.

- There should be a balanced weight between practice and theory in the syllabus.

- Candidates should be equipped with the latest know-how skills.

- There should be sound selection for staff members for these colleges.

- Colleges of education should have clear vision and mission.

- There should be rules and regulation to organize work relations in these colleges.

- We have to establish an inviting educational environment and improvement of student's conditions in the college.

- These colleges should have full financial support.

- There should be a continuous coordination between these colleges and the ministry of education to help success of these colleges' programmes.

\subsection{Some International Educational Experiences}

\subsubsection{India}

The educational system in India has attracted the attention of educators all over the world, as it has achieved tremendous success in all fields. What is the secret behind the success of the Indian experience? What's behind India's success in the global knowledge economy? Das:(2010) thinks that the development of India is the result of the quality of students, but the researcher thinks that the teacher training is behind all of that.The teacher education begins with student having a B.A or B.sc degree in and then s/he joins a one year programme to qualify as licensed teacher. So a B.Ed degree is essential for those willing to grab a job in the government schools. The course offered is one year duration and covers all aspects of education necessary for the future teachers to know in details. Students with bachelor degrees in any discipline from any recognized university are eligible to apply for the course.

\subsubsection{USA Teacher Eligibility}

(The No Child Left Behind Act of 200, (often abbreviated NCLB or pronounced "nicklebee") is a United States Act of Congress concerning the education of children in public schools. NCLB supports standards-based education reform, which is based on the belief that setting high standards and establishing measurable goals can improve individual outcomes in education. There are varied requirements you must meet in order to become a teacher in the United States. Some states also have more strict training and qualifications that are required for you to be able to teach on their state. But the general requirement throughout the United States is that you need to have a license to teach in public schools. (www.romow.com). Generally though, a license is not required for you to teach in a private school. The teaching license is given by the State Board of Education as a rule even though a licensure committee is likewise able to provide the said license. But the overall requirements for almost all of the states in America, require that you have the basic skills and competencies in your chosen field, including your proficiency in reading and writing but most especially in teaching. You should also have the needed expertise and knowledge in your chosen subject. Most schools are now in the process of executing a performance-based system as the basis for the said licensure. This system is an addition to passing the licensure examination in their chosen subjects. You should demonstrate proficiency in teaching your subject. And your teaching performance should be acceptable as well. You should also note that some states have reciprocal agreements that lets teachers from one state to become licensed in another if that is what is agreed upon by the local government. (www.romow.com )

\subsubsection{Europe}

A European-Wide Professional Network for Teacher Education: The important role teacher education has to play in achieving a "Europe of Knowledge" this was recognized by the European Commission in commissioning a 
comprehensive cross-European study (the Sigma project). The aim was to provide an evaluation of the current state of teacher education in the Member States of the European Economic Area and to develop appropriate perspectives to enable teacher education to meet changes and new challenges. The aim was to raise both the problem-awareness and the problem-solving capacity within teacher education in order to contribute to high quality teacher education leading to high quality education and training. This has been attempted through adopting a networking strategy on a European-wide scale. As a Pan-European professional network TNTEE has had frequent requests from various Ministries of Education, committees responsible for teacher education reforms, professional organizations and universities all over Europe dealing with teacher education, to provide input for reforms and improvements of teacher education. (tntee.umu.se/publications/)

\subsection{Future Perspectives of Teacher and Selection Criteria}

Nunan:(1990) thinks that Language teacher education has become fragmented; too often, its efforts focus on ancillary areas such as applied linguistics, methodology, or language acquisition while overlooking the core - teaching itself. He believes that the 'emphasis on these areas, although it may create a pedagogical foundation for the teacher-in-preparation, skirts the central issue of learning to teach.' He proposes refocusing language teacher education on teaching itself by proposing two schemata: (a) a descriptive model that defines teaching as decision-making process based on the skills, attitude, and awareness and (b) educating strategies - training and teaching. He thinks that 'the need to understand the relationship between what we defines language teaching and how it is taught and learned is pressing on both the theoretical and practical levels. It will no doubt strengthen the coherence of our work. We in the Sudan have to raise the same question, but the most important question is not what is the teacher's role will be? but what selection criteria do we need to follow to recruit the right man or woman to do effective teaching?

\subsection{Unwilling Trainees}

In 2001 I was assigned to teach some courses to finalists in one of the leading College of Education in Khartoum. I had about 120 students. I was to teach a topic selected by the students themselves as topic for debate) but they gave me the freedom to choose the topic for them. From my general discussion I found that there was a gap in their knowledge and shaky ideas about teaching. I wanted to know how they thought about teaching. To my astonishment I found that about more than $90 \%$ came to this college unwillingly. They had been there because their achievements in the Sudan School Certificate Examinations did not qualify them for medicine, engineering or economics etc... So education was not their first, second or even the $30^{\text {th }}$ choice. I was very sad for that news but I still had some hope. Then I said,"O.K... Let's say that was not your option then the question remains why have you continued your education since it was not your choice? They said they had nowhere to go. Still there is one more question: let's say that you have spent four years now and had been exposed to a hell of knowledge in education, do you still do not want to go teaching? Almost all of them did not want to teach. I did really feel very sad and told them all about teaching and that an unwilling teacher is very harmful to individual persons as well to the society as a whole. So I begged them if they did not want to be teachers, they should not teach. I told them that behind any failure student there was a failure teacher. I told them that teaching is a helping profession, so if they wanted to help, they should take teaching seriously otherwise they have to quit, letting willing people take over.

\subsection{Competent but!}

Another incident which was behind the writing of this article is that, I had been introduced to (Esra) a young lady to talk to her about her attitudes towards teaching. She was good at English but she was unwilling to teach. She was there in the college of education-because of her achievement in Certificate Examinations. I felt sad because it is very rare to find such a young lady of her age with such a high command of language. When I asked her about what she wanted to achieve, she said she would prefer if she had attended the college of arts or economics because teaching was not in her career plans. I thought we have lost another good teacher.

\section{Conclusion}

New Recruitment Policy: Those two incidents led me to suggest that the future teacher should be selected from among graduates who had already got their first degrees and who are so willingly and desirous want to take education as their future profession. So the education authorities have to abolish all colleges of education and change them into arts and science colleges. Then after getting their first degrees, the person who wants to be a teacher can have one year training courses in education and methodology, as it is the case in India and then s/he can be licensed as a professional teacher. In this way we will be sure that admission to this profession will be to only willing and desirous candidates, who will want to be teachers and who are ready to help in developing mental, physical, psychological and spiritual growth of our young future generations. This new strategy will be feasible for these reasons:

- Financially: This policy is economical as one year training of these graduates is affordable, because it will cost little money. For the training to be affordable, private well-equipped colleges can be established to give B.Ed or 
M.Ed courses for the willing trainees, as it is the case in India. These schools can also co'operate with the government sector to maintain and provide this educational service.

- Academically: We found that students who go to arts colleges are usually high scorers. They have good language programmes at their B.A level. So they will need no more language teaching, but only little training in educational subjects and education-related disciplines to be qualified licensed English or foreign language teachers.

- Virtual classes: As most of these graduates have been exposed to computer courses during their B.A or B.Sc prgrammes, we suppose they are computer literate. If this assumption is correct, then their training can be easier as they could be introduced to courses in distance learning through virtual classes. Establishing Cyber Teacher Training Centres is not very costive as these programmes can a be part of the Sudan Open University with cooperation with IT \& ISP providers.

- Salaries: Improvement in the salary will attract the brighter graduates to join the teaching profession. The government should change the policy of recruitment by guaranteeing appointment for all holders of educational degrees in the general education, as it is the case in Egypt, where teaching attracts the best quality of students. Colleges of education there are sometimes preferred to medical and engineering colleges, as the graduates of these education colleges are immediately offered jobs by the government on their immediate graduation.

- Sustainability: By applying these recruitment strategies we will be sure to secure our future quota of qualified teachers, as these colleges of Arts and Sciences are sustainable human source of willing newcomers to the arena of education profession, then we can annually inject our education institutions' veins with fresh blood.

**Note: I am happy to say that the young lady has changed her mind and she will take teaching for her profession. She wrote me on my wall on the Facebook:" hi, dr, how is it going, i am deeply hoping everything is good. really $i$ miss $u$ so much, and $i$ am in need for your fatherly advice which sustains me to carry on. $i$ wanna tell $u$ that $i$ have changed my mind and i'm longing to be teacher. (Esraa Ali Omar-College of Education -AlZaeem Al-azhari University - Sudan). Then I wrote her back: "Oh Dear How R U. This is a nice piece of news. I have just written an article inspired by you. You will be the first to read it, because it has been made for U. Iam very happy with this news. I hope you will join the profession and find it the most attractive and beautiful job in the world. You will be very happy, because you will see your students mentally grow before your eyes and use those small machines in their heads effectively. Teachers are great people because they are engineers of human behaviour. Teaching is the profession that teaches all professions. GOOD GIRL, greetings once again." $A G S$.

\section{References}

Babiker, Ahmed Ali. (1999). Problem of English language teaching in Higher Secondary Schools in Sudan. Teacher's educational programme. MA thesis U. of K.

Bailey, K. (1990). The use of diary studies in teacher education programmes. In Richards, J. and Nunan, E. (Eds.) Second Language Teacher Education. Cambridge: C.U.P.

Bashir, M. Omer. (1970). Development of Education in Sudan 1898 - 1956. Bierot Dar Elthgafa. (In Arabic).

Barduhn, S. (1989). Review of Maslach, C. 1982 Burnou - The Cost of Caring, London: Prentice-Hall, in Teacher Development. IATEFL SIG Newsletter, 11: 2-3.

Berry, R. (1990). The role of language improvement in in-service teacher training programmes: Killing two birds with one stone. System, Vol. 18, No. 1, p. 97-105. doi:10.1016/0346-251X(90)90032-Z, http://dx.doi.org/10.1016/0346-251X(90)90032-Z

Brickel, H. M., \& Paul, R. H. (1981). Ready for the eighties? A look at foreign language teachers and teaching at the start of the decade. New York: Policies Studies in Education.

Buchberger, F., B. P. Campos, D. Kallos, \& J. Stephenson. (2011). [Online] Available: http://tntee.umu.se/publications/greenpaper.html

Buchmann, M. (1984). The priority of knowledge and understanding in teaching. In L. G. Katz \& J. D. Raths (Eds.), Advances in teacher education. Vol. 1. Norwood, NJ: Ablex.

Corbluth, Julian. The Nile Course for the Sudan. London.

Cullen, R. (1994). Incorporating language improvement in teacher training programmes. ELT Journal, Vol. 48, No. 2, p. 163-171. doi:10.1093/elt/48.2.162, http://dx.doi.org/10.1093/elt/48.2.162

Das, Gurcharan. (2010). Das, Newsweek, 28 February 2006.

Doff, A. (1987). Training materials as an instrument of methodological change. In R. Bowers (Ed.), Language teacher education: An integrated programme for ELT teacher training. ELT Documents, 125, 67-71. Basingstoke, UK: Macmillan for Modern English Publications. 
Eltigani, Mohammed Eltoum. (1966). The role of English in the Sudan - a paper in a conference held at Khartoum University.

Fahmy, J. \& Bilton, L. (1992). Planning a TEFL education program: Policies, perspectives and promise. (ERIC Document Reproduction Service No. ED 369281.

Freeman, D. (1989). Teacher training, development, and decision making: A model of teaching and related strategies for language teacher education. TESOL Quarterly, Vol. 23, No. 1, p. 27-45. doi:10.2307/3587506, http://dx.doi.org/10.2307/3587506

Gradman, H. L. (1971). Foreign language teacher preparation: An integrated approach. Paper presented at the New Mexico Association of Foreign Language Teachers, Albuquerque, NM.

Handal, G. \& P. Lauvas. (1987). Promoting Reflective Teaching: Supervision in Action. Milton Keynes: Open University Press.

Irujo, S. (1993). Letter to the Editor. TESOL Matters, (3)4:22.

Jeffreys, M. (1961). Revolution in Teacher Training. London: Pitman.

Lafayette, R. C. (1993). Subject matter content: What every foreign language teacher needs to know. In G.

Guntermann (Ed.). (1993). Developing teachers for a changing world (pp. 124-158). Lincolnwood, IL: NTC Publishing Group.

Lange, D. L. (1990). A blueprint for a teacher development program. In J. Richards \& D. Nunan (Eds.), Second language teacher education. Cambridge, U.K.: Cambridge University Press.

Mohammed, \& A/Ghani Ibrahim. (2009). Evaluation of Sudanese experience in teacher training. [Online] Available: http://www.wrc.org.sd/tagweem.htm

Morain, G. (1990). Preparing foreign language teachers: Problems and possibilities. ADEFL Bulletin, Vol. 21, No. 2, p. 20-24. doi:10.1632/adfl.21.2.20, http://dx.doi.org/10.1632/adfl.21.2.20

Obama, Barak. (2011). [Online] Available: http://mwcta.blogspot.com/2009/08/congress-targets-chinese-language.html.

Rajaa, Abdelaziz Ali. (2004). ISETI; Past and Present: Khartoum ISETI (in Arabic).

Reilly, D. H. (1989). A knowledge base for education: Cognitive science. Journal of Teacher Education, Vol. XXXX, No. 3, p. 9-13. doi:10.1177/002248718904000302, http://dx.doi.org/10.1177/002248718904000302

Sandell, Liza. (1988). English Language in Sudan a history of its teaching and politics. Ithoea press. London.

Schotta, S. (1973). Student evaluation and foreign language programs: A case study. Foreign Language Annals, Vol. 6, 6 No. 4, p. 502. doi:10.1111/j.1944-9720.1973.tb02630.x, http://dx.doi.org/10.1111/j.1944-9720.1973.tb02630.x

Schrier, L. L. (1989). A survey of foreign language teacher preparation patterns and procedures in small, private colleges and universities in the United States. Unpublished doctoral dissertation, Ohio State University, Columbus,

p. 69-74.

(1994). Understanding the foreign language teacher education process. ADFL Bulletin, Vol. 25, No. 3 ,

Shulman, J.H. (1991). Revealing the mysteries of teacher-written cases: Opening the black box. Journal of Teacher Education, (42)4:250-262. doi:10.1177/002248719104200403, http://dx.doi.org/10.1177/002248719104200403

Stones, E. (1984). Supervision in Teacher Education. London: Methuen.

Valli, L., \& TOM. A. (1988). How adequate are the knowledge base frameworks in teacher education? Journal of Teacher Education, Vol. XXXIX, No. 5, p. 5-12. doi:10.1177/002248718803900503, http://dx.doi.org/

Widdowson, H. (1983). Learning Purpose and Language Use. Oxford: O.U.P.

-------. (1984). The incentive value of theory in teacher education. ELT Journal, 38/2: 86-90. doi:10.1093/elt/38.2.86, http://dx.doi.org/10.1093/elt/38.2.86

O.U.P.

(1990). Pedagogic research and teacher education. In Aspects of Language Teaching. Oxford:

Williams, M. (1994). Teacher training for English language teachers. In G.R. Harvard \& P. Hodkinson (Eds.), Action and reflection in teacher education (pp. 213-227). Norwood, NJ: Ablex.

Yeddi, Abd Al Rohman Mohammed. (2003). History of English Language in Sudan. Da watprinting New Delhi. India. 